\title{
Effect of temperature on settlement and postsettlement survival in a barrens-forming sea urchin
}

\author{
José Carlos Hernández ${ }^{1,2, *}$, Sabrina Clemente ${ }^{1,2}$, Dominique Girard ${ }^{1}$, \\ Ángel Pérez-Ruzafa ${ }^{3}$, Alberto Brito ${ }^{1}$ \\ ${ }^{1}$ Departamento de Biología Animal Biodiversidad, Ecología Marina y Conservación (Ciencias Marinas), Facultad de \\ Biología, Universidad de La Laguna, La Laguna, Tenerife, islas Canarias \\ ${ }^{2}$ Biology Department, Villanova University, 800 Lancaster Avenue, Villanova, Pennsylvania 19085, USA \\ ${ }^{3}$ Departamento de Ecología e Hidrología, Universidad de Murcia, Murcia, España
}

\begin{abstract}
Large populations of the sea urchin Diadema aff. antillarum occur in the east Atlantic archipelagos. The origin and stability of these large herbivorous populations are not well known. Variability in settlement, recruitment and adult urchin density were quantified and compared over a 7 yr period (2002 to 2008) within the Canary Islands. Variables that potentially affect urchin settlement such as gonad index, temperature and primary productivity (phytoplankton) were measured. Settlement was found to be high during warm years; temperatures $>24^{\circ} \mathrm{C}$ induced important settlement pulses. Postsettlement survival in barren areas of Tenerife was exponentially and positively correlated with seawater temperature changes, while very low to 0 survival was found at macroalgal beds off El Hierro. Assuming that climate change predictions are correct, the strong positive relationship between thermal history and postsettlement survival of this ecologically important species suggests that barren grounds will persist as seawater warms up if no mass mortality occurs. This future scenario will have important implications for the stability of algal beds and coastal ecosystems as a whole.
\end{abstract}

KEY WORDS: Diadema aff. antillarum $\cdot$ Larval settlement $\cdot$ Seawater warming $\cdot$ Recruitment $\cdot$ Habitat

\section{INTRODUCTION}

In subtidal ecosystems, destructive grazing due to sea urchin population outbreaks frequently causes an ecological disequilibrium, a situation that has been observed globally (Lawrence 1975, Watanabe \& Harrold 1991, Hagen 1995, Guidetti \& Sala 2007, Ling 2008, Hernández et al. 2008a). Urchin hyperabundance results in unproductive barrens that are highly persistent (Knowlton 2004) and can damage the local economy (Hughes et al. 2005). These altered states also have major impacts on the marine ecology of the area, affecting macroalgae-dominated rocky reefs (Ling 2008) and the important marine resources that they support (Pinnegar et al. 2000, Shears \& Babcock 2002). However, factors controlling urchin population size are still poorly understood (Norderhaug \& Christie 2009, Uthicke et al. 2009).
The establishment and stability of urchin barrens are likely the result of continuous predator overexploitation (Steneck et al. 2002, Guidetti \& Sala 2007, Clemente et al. 2009). However, the interplay of other key environmental factors, such as oceanographic conditions or habitat features (Scheibling 1996, Pinnegar et al. 2000, Hernández et al. 2008a), can promote positive feedback mechanisms that trigger and maintain the high urchin densities (Guidetti \& Sala 2007). The lack of quantitative studies across broad spatial and temporal scales in many places of the world limits our understanding of the dynamics of urchin outbreaks, their effects on macroalgal beds, and the potential role of oceanographic changes in mediating transitions between the 2 community states (algal bed vs. barren). Conversely, urchin population dynamics and their implications for these transitions have been particularly well studied in some temperate regions (e.g. 
eastern Canada; Scheibling 1986, Lauzon-Guay \& Scheibling 2007).

It is well known that temperature regulates larval development and higher temperatures facilitate faster larval growth (Thorson 1950, Hoegh-Guldberg \& Pearse 1995) and urchin reproduction (Ling et al. 2008). Temperature has been considered an important causative factor in the destruction of macroalgal beds by sea urchin grazing (Hart \& Scheibling 1988, Ling et al. 2008). However, in population ecology, it is not always easy to establish causative effects due to the lack of historical data or baseline studies. The link between sea surface temperature and destructive grazing due to the rapid development that urchin larvae experience in warmer waters seems an oversimplistic model that requires further study. This relationship may apply for some sea urchin species, but not for others in which recruitment is inversely related to high temperatures. For example, Strongylocentrotus purpuratus recruits around southern California are more abundant following cold winter episodes (Ebert 1983), and low temperatures seem to favour high recruitment of $S$. droebachiensis in the coast of Norway (Sivertsen 2006). In any case, understanding the influence of abiotic factors on urchin populations is necessary to predict the consequences of seawater warming that is associated with large-scale climate change. This is of particular interest in the study of population dynamics in thermophilous species such as Diadema aff. antillarum, which is particulary sensitive to water warming processes and is a key herbivore.

The relevance of larval supply in regulating populations of meroplanktonic benthic invertebrates is widely recognized for many species (Connell 1985, Caley et al. 1996). Subsequent recruitment dynamics in complex life cycles are very unpredictable as it involves several stages, each of which can occur in a different habitat (Roughgarden et al. 1988). Studying sea urchin recruitment supply processes is particularly relevant to coastal marine communities of the east Atlantic archipelagos, where productive macroalgal beds that remain only in some parts of the islands (Hernández et al. 2008b), are vulnerable to severe urchin grazing (Hernández et al. 2008a). In Madeira, Selvagean Islands and Canary Islands, urchins can dominate waters up to $\sim 50 \mathrm{~m}$ in depth and cover $\sim 89 \%$ of the total littoral rocky bottoms (Hernández et al. 2008b), generating biodiversity loss and affecting many ecosystem services (Clemente 2007). Yet few studies in these archipelagos have assessed the influence of environmental and biological factors in determining Diadema aff. antillarum population size and dynamics (Hernández 2006, Clemente 2007, Hernández et al. 2008a).

In 2002, we began to investigate how coastal oceanographic seasonality may influence the dynamics of
Diadema aff. antillarum larvae and ultimately urchin population density around the Canary Islands. We aimed to determine (1) the oceanographic variables that influence sea urchin settlement, including seawater temperature, phytoplankton and gamete production; and (2) the relationship between settlement rates, recruitment, and density of adult urchins. Barren and macroalgal habitats were sampled throughout the Archipelago to also assess the influence of any potential habitat related feature on postsettlement survival (PS). Finally, we aimed to (3) reconstruct the PS history from 1948 to 2007 using the relationship between temperature and PS. From the seawater thermal records, we then established when temperature became a factor determining sea urchin outbreaks in an ecological scenario already disturbed by humans.

\section{MATERIALS AND METHODS}

Sea urchin settlement. We defined settlement as the monthly appearance of newly settled Diadema aff. antillarum individuals on artificial samplers described by Hernández et al. (2006a). The smooth, dark interior of these collectors, consisting of 100 moulded $3.9 \mathrm{~cm}$ diameter plastic balls (biofilters) placed into a mesh bag, provided a large surface area that is favorable for Diadema larval settlement and subsequent metamorphosis. This type of collector also facilitated ease of replication and separation of settlement from postsettlement processes (Harrold et al. 1991).

Settlement collectors were used at 3 urchin barren sites around Tenerife Island (Masca, Abades and Boca Cangrejo), and at 4 macroalgal bed sites around El Hierro Island (Roque Chico, Punta de los Frailes, La Caleta and Tamaduste) (Fig. 1). Collectors were deployed between April 2002 and April 2008 at Abades; between May 2002 and April 2003 at Masca; and between December 2003 and April 2008 at Boca Cangrejo. In El Hierro, collectors were placed during the annual settlement peak in 2006 (October, based on previous data from Hernández et al. 2006a). At each site, 3 replicate samplers were deployed at 6 to $10 \mathrm{~m}$ depth (placed $1 \mathrm{~m}$ above the seafloor) and replaced every month using the method described by Hernández et al. (2006a). The number of newly settled Diadema aff. antillarum for each sampling period was determined using a dissecting microscope.

Sea urchin recruitment. We defined early recruitment as the appearance of small Diadema aff. antillarum individuals $\geq 4$ and $<6 \mathrm{~mm}$ in test diameter (TD) in $0.25 \mathrm{~m}^{2}$ quadrats that were randomly placed over the natural substrate. Individuals with TDs that were $<4 \mathrm{~mm}$ could not be reliably discerned in underwater quadrats. 


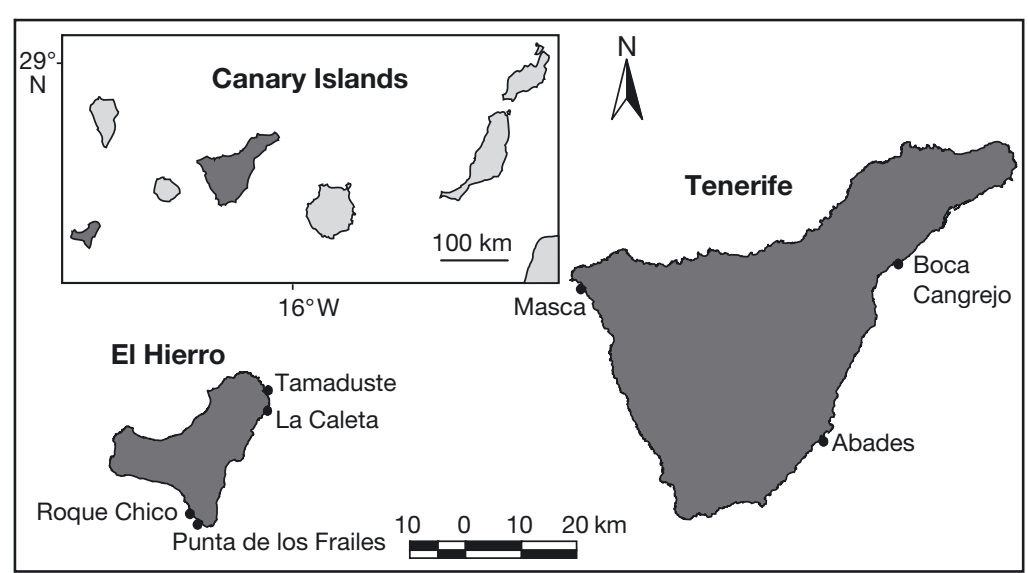

Fig. 1. Canary Islands and study sites at Tenerife and El Hierro Islands

$(<20 \mu \mathrm{m})$ and nanoplankton $(2-20 \mu \mathrm{m})$. Culturing procedures suggest that larvae of the sibling species Diadema antillarum feed on phytoplankton (Eckert 1998). In the oligotrophic waters of the Canary Islands, picoplankton represent as much as $94 \%$ of the phytoplankton biomass and 50 to $90 \%$ of the primary production (Braun \& Molina 1984). Measurements of phytoplankton productivity through the Steeman-Nielsen ${ }^{14} \mathrm{C}$ method (SteemanNielsen 1952) were used as an indirect measure of picoplankton availability. Monthly gonad indices were determined in 30 sea urchins as an indirect measure of monthly spawning effort (Hernández et al. 2006b). The suitability of the gonad index

In 3 barren sites around Tenerife, monthly abundances of juvenile Diadema aff. antillarum were recorded from June 2002 to July 2005 at Abades; from June 2002 to March 2003 at Masca; and from July 2003 to July 2005 at Boca Cangrejo. At Abades and Boca Cangrejo, 20 randomly placed quadrats on hard substrate were used to sample urchins along a transect line (5 to $10 \mathrm{~m}$ depth), while only 10 quadrats were sampled at Masca along a deeper transect (10 to $12 \mathrm{~m}$ depth) due to logistic constraints. During the annual recruitment peak in December 2006, 4 additional sites (macroalgal beds) were sampled in El Hierro (Tamaduste, La Caleta, Roque Chico and Punta de los Frailes). Numbers of replicates were based on a previous study that determined the minimum sample size suitable for these rocky bottoms (Hernández 2006).

Densities of adult sea urchins. Adult Diadema aff. antillarum densities were determined using the belt transect method, counting all individuals that were $>20 \mathrm{~mm}$ in TD in $10 \times 2 \mathrm{~m}$ linear transects. Monthly sampling was done at Abades from February 2002 to February 2005 with gaps during 2003, and during some months in 2005 and 2006. Masca was sampled from February 2002 to March 2003 and during May 2006. At Boca Cangrejo monthly sampling was done from January 2004 to February 2005, and during some months in 2002, 2005 and 2006. At Boca Cangrejo, additional density measurements were taken in November 2002 and during several other months in 2005, 2006 and 2007. In October 2006, additional sites (macroalgal beds) were sampled around El Hierro Island (Tamaduste, La Caleta, Roque Chico and Punta de los Frailes).

Temperature, food availability and spawning. Temperature and food (phytoplankton) availability were measured monthly for $2 \mathrm{yr}$ at Abades and Boca Cangrejo. Many echinoderm larvae feed on particles $<50 \mu \mathrm{m}$ in size (McEdward \& Miner 2001), i.e. picoas an appropriate measure of spawning is supported by previous gametogenic studies, which suggest that spawning occurs when the gonad index decreases during May-June in the Canary Islands (Hernández et al. 2006b).

Data analysis. Urchin settlement rates were compared between years and sites using a 2-way distancebased permutational ANOVA (Anderson 2001). Summer temperatures $>24^{\circ} \mathrm{C}$ are uncommon for the Canary Islands region but have been observed in recent years (Braun \& Molina 1984; but see Fig. 3b); thus, to test the effect of this uncommon temperature on Diadema aff. antillarum settlement, 'temperature, $T$ was treated as a fixed factor with 2 levels (normal years with $T<24^{\circ} \mathrm{C}$ and uncommon warmer years with $T>24^{\circ} \mathrm{C}$ ). Based on previous data (Hernández et al. 2006a) and data presented here, settlement rates in Abades were always higher than in Boca Cangrejo; thus, to test the effect of this difference in $D$. aff. antillarum settlement, 'site' was treated as a fixed factor with 2 levels (high or low settlement rate site). The long-term settlement monitoring series at Abades and Boca Cangrejo (2004 to 2007) was used for this comparison. Analysis was based on Euclidean distances of raw data, with p-values being obtained using 4999 permutations of the appropriate exchangeable units (Anderson 2001).

Settlement and recruitment rates, as well as adult densities, were compared between islands (Tenerife vs. El Hierro) and sites, using the same permutation procedure. 'Island' was treated as a fixed factor with 2 levels and 'site' was treated as a random factor nested in 'island', with 6 levels (Abades, Boca Cangrejo, Tamaduste, La Caleta, Roque Chico and Punta de los Frailes). The software PRIMER 6 \& PERMANOVA+ was used to perform all statistical procedures.

Regression analyses were used to examine the relationship between mean settlement during the 3 mo settlement peak each year (2002 to 2004) and subse- 
quent mean recruitment during the 3 mo recruitment peak, following Lamare \& Barker (2001). This regression was carried out on data from 2002 to 2005, using each combination of site and year. Logarithmic transformation $(\log [\mathrm{x}+1])$ of the means strengthened the relationship. To examine the relationship between mean recruitment during peak recruitment and adult density, we used the mean adult density of the following year, after a minimum delay of 12 mo for each site. Twelve months is the approximate length of time for a $4 \mathrm{~mm}$ sized urchin (the size at which urchins are first detected in the adult habitat) to reach a reproductively viable adult size $(20 \mathrm{~mm})$. This time period was calculated using growth rates obtained for Diadema aff. antillarum from recruit size frequency data (Hernández 2006). Growth rates were similar to those found for D. antillarum (Hawkins \& Lewis 1982, Bak 1985).

A multiple linear regression model (generalised linear model, GLM) with stepwise forward selection of variables including temperature, food availability and spawning effort (using $\mathrm{p}<0.05$ as the inclusion and/or rejection criterion), was used to determine the best linear model accounting for the observed variation in settlement estimates. To explore the response of variables at different time scales, 3 different matrices were used in the analyses: (1) raw, (2) squared and (3) cubed data. Different time lags between settlement estimates and the remaining variables were also considered, thus adding 2 new columns to the raw data matrix, using lag times of $1(t+1)$ and $2(t+2)$ mo.

The PS of Diadema aff. antillarum was calculated by subtracting the mean recruitment rate (recruits $\mathrm{m}^{-2}$ ) during the annual recruitment peak (NovemberJanuary) from the mean settlement rate (settlers $\mathrm{m}^{-2}$ ) during the settlement peak (August-October) for each site and year where data were available (see Table 2). PS was then correlated with seawater temperature. Historical sea surface temperature (SST) data were calculated using the National Center for Environmental Prediction / National Center for Atmospheric Research (NCEP/NCAR) reanalysis data for the Canary Islands (Kalnay et al. 1996).

\section{RESULTS}

\section{Spatio-temporal patterns of larval settlement: normal vs. uncommon warmer years}

Urchins that settled in collectors consisted of postlarvae and newly metamorphosed juveniles. No larvae were found. The mean TD of newly settled Diadema aff. antillarum was $0.75 \pm 0.17 \mathrm{~mm}(\mathrm{n}=150)$. A single settlement peak occurred during August-October, which was consistent across years and sites (Fig. 2a).
Early postlarvae and newly metamorphosed juveniles were collected throughout the study period, except in some May, June and July samples where no individuals were found. The months in which no settlement occurred varied with site and year (Fig. 2a). Strong spatial and temporal variability in settlement quantity was found, with the qualitative settlement pattern being consistent in space and time (Fig. 2a). Settlement was generally higher at Abades in all years and was highest in 2006 (Fig. 2a). Scatter plots of sites show a positive correlation between settlement and seawater temperature for Abades and Boca Cangrejo (Fig. 2b). No correlation was found in Masca, which could be due to the lack of sufficient data.

Permutational ANOVA that was conducted for settlement peak data recorded between 2004 and 2007 in Abades and Boca Cangrejo showed significant effects of the factors 'temperature' and 'site' (Table 1a). The abundance of newly settled larvae was higher during warm years (2004 and 2006) and Abades showed higher settlement rates than Boca Cangrejo (Fig. 3a). No significant differences in settlement between islands and sites were observed during 2006 (Table 1b).

Temperature was the most significant factor determing the variability in Diadema aff. antillarum settle-

Table 1. Diadema aff. antillarum. Summary of the 2-way permutational (perm) ANOVAs to assess significant differences in (a) settlement between cold and warm years (cold: 2005 and 2007; warm: 2004 and 2006) at sites with different settlement rates (high: Abades; medium: Boca Cangrejo; low: Masca); (b) settlement between islands during 2006; (c) recruitment between islands during 2006; and (d) adult densities between islands during 2006

\begin{tabular}{|lcccc|}
\hline Effect & df & SS & Pseudo-F & p (perm) \\
\hline (a) Settlement & & & & \\
Temperature & 1 & 729.43 & 7.691 & 0.0057 \\
Site & 1 & 1357.6 & 14.314 & 0.0002 \\
T $\times$ S & 1 & 101.31 & 1.0682 & 0.3096 \\
Residual & 80 & 7587.5 & & \\
Total & 83 & 9972.9 & & \\
(b) Settlement & & & & \\
Island & 1 & 720 & 2.342 & 0.2056 \\
Site (Island) & 4 & 1052.1 & 2.753 & 0.0555 \\
Residual & 24 & 2292.6 & & \\
Total & 29 & 4064.7 & & \\
(c) Recruitment & & & & \\
Island & 1 & 5.00 & 6.312 & 0.0690 \\
Site (Island) & 4 & 3.17 & 6.042 & 0.0003 \\
Residual & 90 & 11.81 & & \\
Total & 95 & 19.99 & & \\
(d) Adult density & & & & \\
Island & 1 & 1001 & 68.561 & 0.0017 \\
Site (Island) & 4 & 58.40 & 9.604 & 0.0001 \\
Residual & 42 & 63.85 & & \\
Total & 47 & 1123.30 & & \\
\hline
\end{tabular}




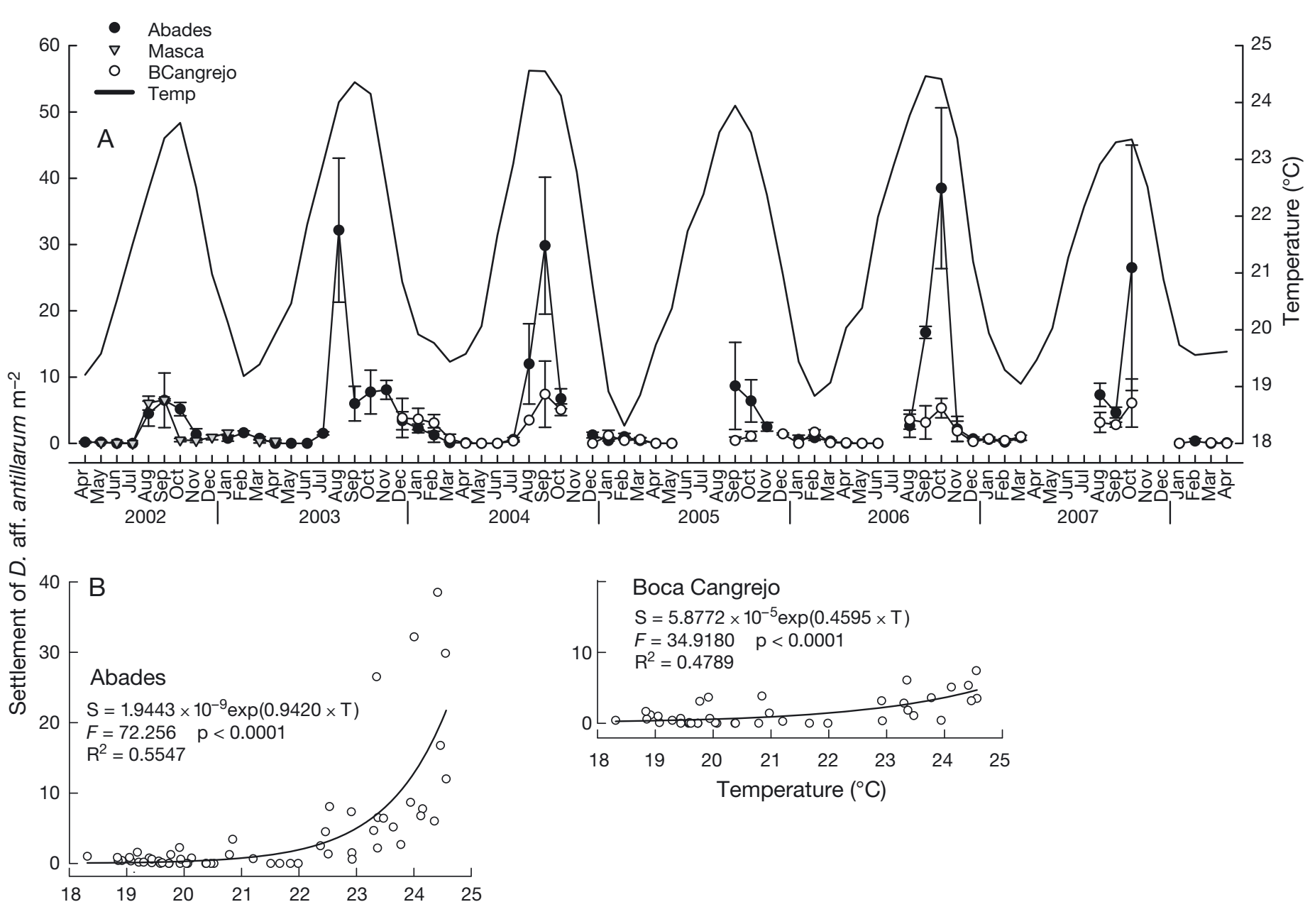

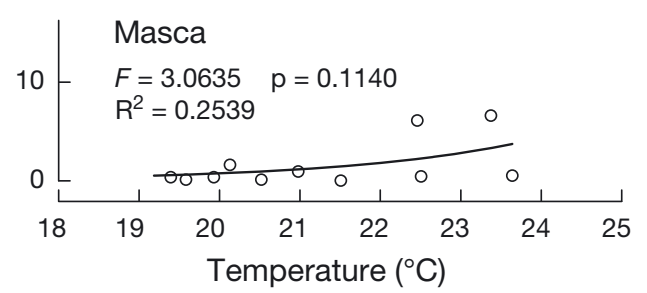

ment (Table 2, Fig. 2). However, settlement rate was also negatively correlated with phytoplankton availability (food source) 2 mo before the settlement period (Table 2).

\section{Spatio-temporal patterns of recruitment}

New recruits $(<6 \mathrm{~mm})$ were observed in the field during November-January at every site and in every year studied. During 2002 and early 2003, recruitment was very low compared with that of 2003-2004 and 2004-2005. Abades had consistently higher urchin recruitment than Masca and Boca Cangrejo (Fig. 4, Table 3). During 2006, recruitment rate did not differ between islands but differed significantly between sites (Table 1c). Abades consistently recorded the highest urchin recruitment rates (Table 3).

\section{Spatio-temporal patterns of adult densities}

Adult Diadema aff. antillarum density differed between months and sites (Fig. 4). The variation in urchin densities remained relatively constant until 2005 when a noticeable increase was observed (Fig. 4). During 2006, there were significant differences in density between islands and sites. Tenerife had consistently higher densities, while Abades showed the highest urchin densities among all sites (Table 1d, Table 3). 


\section{Relationships between settlement, recruitment and adult density}

Diadema aff. antillarum settlement was found to strongly affect recruitment, with $74 \%$ of the recruitment variation being explained by settlement variation. In 2002, urchin settlement was low, and recruitment in the subsequent months was also low. Larger settlement events occurred in 2003 and 2004, and recruitment in 2004 and 2005 was also higher (Fig. 4, Table 4). Regression performed between mean recruitment peak and adult urchin density recorded $\sim 12$ mo later showed that adult sea urchin densities were significantly affected by the recruitment events in the preceding months (Fig. 4, Table 4).

Despite the significant correlations between settlement and recruitment and between recruitment and adult density, the pattern was clearly different between islands (Tenerife vs. El Hierro). There was no difference in settlement rates between islands and sites (Table 1b), but recruitment differed significantly between sites studied at both islands (Table 1c). The effect of recruitment on adult densities was only clear in Tenerife, while PS was small to 0 at El Hierro during 2006 (Table 3).

\section{Effect of temperature on PS}

Diadema aff. antillarum PS was exponentially and positively correlated with seawater temperature changes in Tenerife (Fig. 5). PS in El Hierro was very low (Fig. 5).

\section{Reconstructed PS pattern using historical temperature data}

Pulses of higher PS (\%) have been more frequent since the early 80 s, coinciding with a significant increase in seawater temperature during recent decades (Fig. 6a,b). Seawater temperatures have been particularly important in controlling urchin abundances in recent years when mean summer temperatures have reached $>24^{\circ} \mathrm{C}$ (Fig. 3b). Pearson correlation between PS estimates and temperatures was positive and significant $(\mathrm{r}=0.804, \mathrm{p}<$ $0.01, \mathrm{~N}=59$ ).

Table 2. Summary of multiple regression analyses using settlement as the dependent variable. Temperature, phytoplankton and gonad index were used as independent variables. ${ }^{2}$ or ${ }^{3}$ indicate that the variable is a square or cubic exponential. '-2' following an independent variable indicates that it corresponds to a 2 mo lag

\begin{tabular}{|lccccc|}
\hline Independent var. & Coefficients & SE & Std Coef. & $p$ & Tolerance \\
\hline Constant & -15539.897 & 4544.026 & 0.000 & $<0.01$ & $<0.01$ \\
Temperature & 2223.837 & 626.180 & 196.504 & $<0.01$ & 0.000 \\
Temperature $^{2}$ & -105.800 & 28.651 & -406.949 & $<0.01$ & 0.000 \\
Temperature $^{3}$ & 1.674 & 0.435 & 211.415 & $<0.0001$ & 0.839 \\
Phytoplankton-2 & -0.821 & 0.198 & -0.373 & & \\
Model: $F=29.265 ; \mathrm{p}<0.001 ; \mathrm{R}^{2} \mathrm{aj} .=0.769$ & & & & \\
\hline
\end{tabular}

Table 3. Diadema aff. antillarum. Larval settlement peak, recruitment peak, adult density: means \pm SD. Postsettlement survival (PS) percentage at different sites and years sampled during this study

\begin{tabular}{|c|c|c|c|c|c|c|}
\hline & Site & Year & Settlement $\mathrm{m}^{-2}$ & Recruitment $\mathrm{m}^{-2}$ & Adults $\mathrm{m}^{-2}$ & PS (\%) \\
\hline \multirow[t]{11}{*}{ Barren areas } & Masca & 2002 & $4.38 \pm 2.97$ & $0.03 \pm 0.02$ & $9.95 \pm 1.48$ & 0.68 \\
\hline & Abades & 2002 & $5.39 \pm 2.49$ & $0.18 \pm 0.10$ & $10.44 \pm 1.07$ & 3.34 \\
\hline & & 2003 & $15.31 \pm 13.94$ & $3.14 \pm 1.89$ & $11.20 \pm 0.35$ & 20.51 \\
\hline & & 2004 & $16.2 \pm 12.09$ & $5.20 \pm 2.12$ & $15.50 \pm 4.50$ & 32.10 \\
\hline & & 2005 & $7.54 \pm 4.78$ & - & - & - \\
\hline & & 2006 & $19.31 \pm 16.79$ & $0.81 \pm 0.75$ & $11.76 \pm 2.86$ & 4.21 \\
\hline & & 2007 & $12.83 \pm 13.89$ & - & - & - \\
\hline & Boca Cangrejo & 2004 & $5.33 \pm 3.06$ & $1.67 \pm 0.92$ & $6.17 \pm 0.71$ & 31.33 \\
\hline & & 2005 & $0.75 \pm 0.67$ & & & \\
\hline & & 2006 & $4.03 \pm 1.91$ & $0.187 \pm 0.40$ & $8.00 \pm 0.91$ & 4.64 \\
\hline & & 2007 & $4.03 \pm 2.51$ & - & - & - \\
\hline \multirow[t]{4}{*}{ Macroalgal beds } & La Caleta & 2006 & $1.25 \pm 0.25$ & $0.06 \pm 0.25$ & $0.62 \pm 0.33$ & 1.25 \\
\hline & Tamaduste & 2006 & $2.08 \pm 1.28$ & 0 & $0.04 \pm 0.05$ & 0 \\
\hline & Roque Chico & 2006 & $1.33 \pm 0.76$ & 0 & $0.02 \pm 0.04$ & 0 \\
\hline & Pta de los Frailes & 2006 & $2.00 \pm 0.90$ & 0 & $0.07 \pm 0.06$ & 0 \\
\hline
\end{tabular}



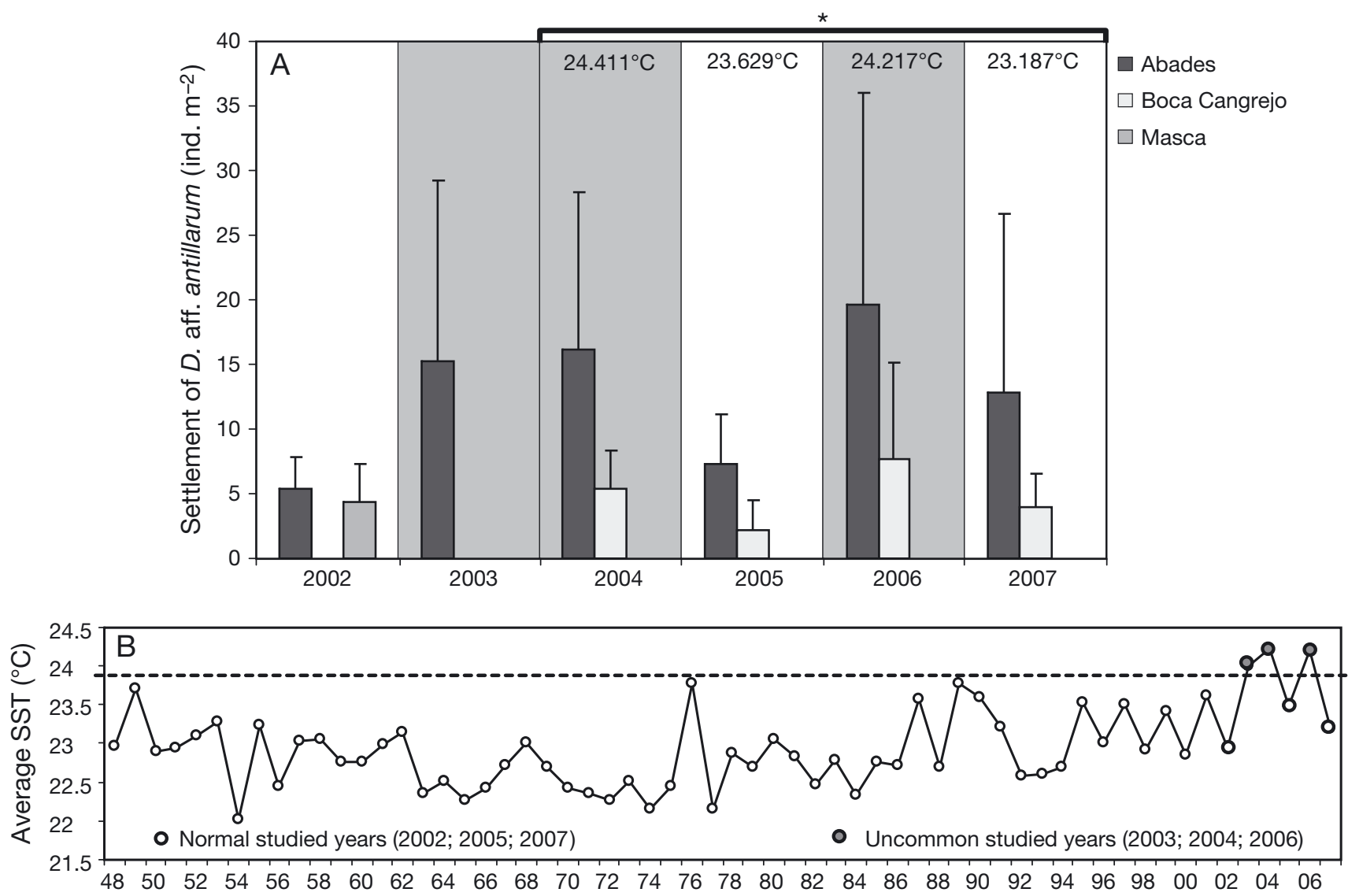

Fig. 3. Diadema aff. antillarum. (A) Settlement peaks (August-October) in different years and temperature regimes (mean \pm SD). Shaded background: uncommon warm years $\left(\mathrm{T}>24^{\circ} \mathrm{C}\right)$. White background: normal years $\left(\mathrm{T}<24^{\circ} \mathrm{C}\right)$. $\left({ }^{*}\right)$ Site and years included in the analysis. (B) Average sea surface temperatures (SST) for the settlement period (August-October) from 1948 to 2007 , showing the uncommon warm years studied (temperatures $>24^{\circ} \mathrm{C}$ )

\section{DISCUSSION}

\section{Effect of oceanographic seasonality and island on PS}

Strong temporal and spatial variability in settlement has commonly been observed in both temperate (Rowley 1989, Ebert et al. 1994, Balch \& Scheibling 2000, Lamare \& Barker 2001, Hereu et al. 2004) and tropical sea urchins (Bak 1985, Keesing et al. 1993, Hernández et al. 2006a). Despite Diadema aff. antillarum showing clear spatial and temporal variation in settlement in this study, an underlying pattern that was consistent among study sites for $7 \mathrm{yr}$ was detected. The settlement pattern was unimodal, with the main peak occurring in late summer to early autumm (August, September and October). Although there was a single clear settlement peak, postlarvae and early juveniles were detected during other months as well, except during spring (April-June), when no settlement was recorded. In other long-term studies in temperate ecosystems, a major unimodal peak in settlement has also been found (Rowley 1989, Harrold et al. 1991, Ebert et al. 1994, Balch \& Scheibling 2000).
The peak in Diadema aff. antillarum settlement occurred after the spawning period. Gonad index peaked in April-June and spawning is presumed to occur shortly thereafter, at the point in time when gonad index decreases (Hernández 2006, Hernández et al. 2006a). For the sibling species D. antillarum, larvae are thought to have a planktonic period of $\sim 4$ to $6 \mathrm{wk}$ (Eckert 1998). In our study, a 2 mo lag existed between the end of the peak spawning period and the beginning of the settlement peak. Despite spatial variations (between islands and sites), temperatures $>24^{\circ} \mathrm{C}$ increased sea urchin settlement. A general trend of increasing settlement intensity was observed at study sites during 2004 and 2006, and higher settlement rates were found to coincide with warmer years. Although 2002 was excluded from the analysis to avoid imbalance, it is worthy to highlight that this was the coldest year and settlement rates were also lowest at this time in 2 sites (Abades and Masca).

Our results coincide with Thorson's (1950) hypothesis, which maintains that temperature causes among and within species variation in larval development and duration. Temperature enhances settlement by accel- 


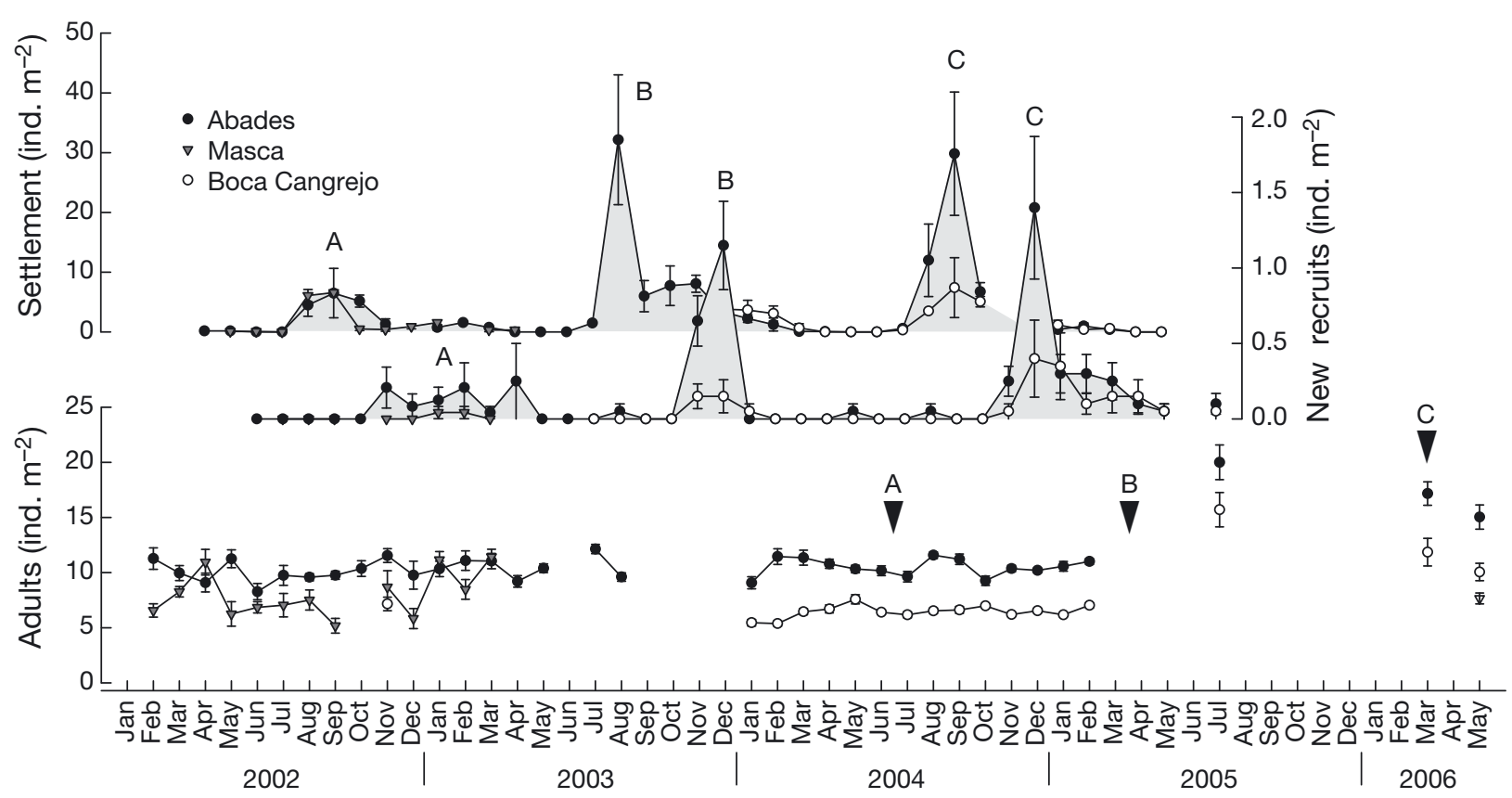

Fig. 4. Diadema aff. antillarum. Monthly temporal variation in larval settlement, new recruits and adult urchin abundance (all values mean $\pm \mathrm{SD}$, urchins $\mathrm{m}^{-2}$ ) at 3 sites on Tenerife Island (Abades, Masca and Boca Cangrejo) over 5 yr. Letters A,B,C refer to urchin cohorts. V: point of time when urchins that settled during August-October can first be seen in the adult population (reaching $>20 \mathrm{~mm}$ in test diameter)

erating larval development and reducing the period that larvae are exposed to planktonic predators, as has been shown in laboratory and field experiments for several echinoderms (Hart \& Scheibling 1988, HoeghGuldberg \& Pearse 1995). However, other studies have found an inverse relationship between urchin recruitment and seawater temperature during larval development (Ebert 1983, Himmelman 1986). Cold waters are often associated with nutrient richness, and it is hypothesized that it is the nutrient content that favours urchin development (Boidron-Metairon 1995) and subsequent settlement and recruitment of certain species (Ebert 1983). Alternatively, cold nutrient rich waters may trigger phytoplankton blooms that are thought

Table 4. Diadema aff. antillarum. Relationships between (1) settlement and annual recruitment, and (2) annual recruitment and annual adult density for the studied populations. Settlement is expressed as the mean number of newly settled urchins recovered from the settlement collectors in the settlement season. Annual recruitment is expressed as the maximum number of early stage sea urchins ( $<6 \mathrm{~mm}$ test diameter) in the postsettlement period. Annual adult density is expressed as the mean number of adult sea urchins $(>20 \mathrm{~mm})$ in the postrecruitment period $(\approx 12 \mathrm{mo}$ based on growth rates estimated by Hernández 2006). The linear relationship is expressed for pooled sites ( 7 and 8 sites for (1) and (2) respectively)

\begin{tabular}{|lcccc|}
\hline & $\mathrm{R}^{2}$ & $F$ & $\mathrm{p}$ & Equation \\
\hline 1. Settlers/New recruits & 0.7451 & $26.310<0.0001$ & $y=0.3613 x-1.8001$ \\
2. New recruits/Adults & 0.4327 & 6.864 & $<0.05$ & $y=2.1647 x+4.4348$ \\
\hline
\end{tabular}

to be synchronized with urchin spawning, thereby improving their reproductive success (Starr et al. 1990). In our study, Diadema aff. antillarum settlement was negatively related to food availability (phytoplankton production in the 2 mo preceding settlement), which indicates that $D$. aff. antillarum larvae are in the plankton, and are able to reach competence when no or very tle food is available. According to Hoegh-Guldberg Pearse (1995), temperature, rather than food or any ther variable, best explains developmental rates in ter 2008) and our results concur that $D$. aff. antillarum is well adapted to the oligotrophic waters around the Canaries (Hernández 2006).

Temperatures $>24^{\circ} \mathrm{C}$ induce high urchin settlement rates and favour PS. Years with summer temperatures $>23^{\circ} \mathrm{C}$ have been more frequent since the early 80s and a parallel increase in urchin population density has been detected (Hernández et al. 2008a). Increased temperatures that are predicted to result from global climate change (Harley et al. 2006, IPCC 2007), combined with other human impacts such as overfishing of the urchins' natural predators (Worm et al. 2006), will probably result in an environment that is increasingly favourable to this 


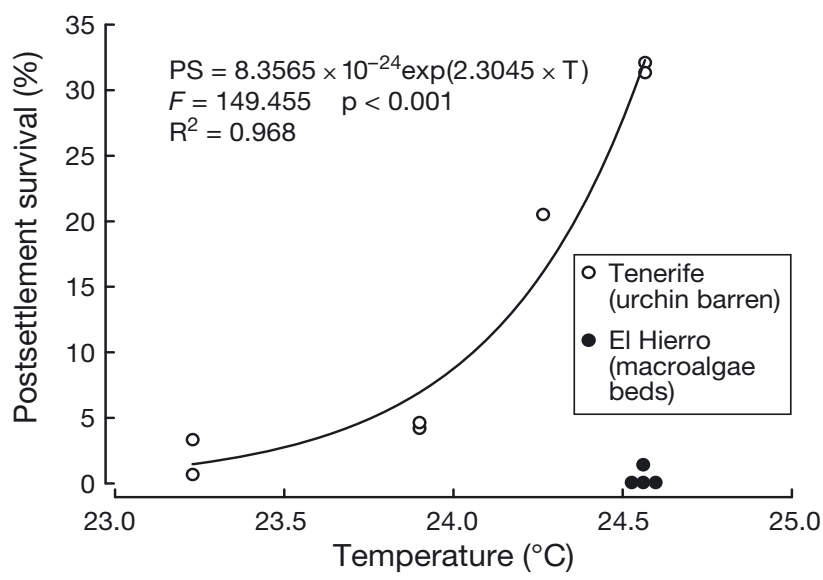

Fig. 5. Diadema aff. antillarum. Postsettlement survival (PS) at different seawater temperatures in contrasting habitats (urchin barrens and macroalgal beds). PS was calculated by subtracting the mean recruitment rate (recruits $\mathrm{m}^{-2}$ ) during the recruitment annual peak (November-January) from the mean settlement rate (settlers $\mathrm{m}^{-2}$ ) during the settlement annual peak (August-October) for each site and year where data were available (see Table 3 )

invertebrate. There are already numerous worldwide examples of altered ecosystem states in which rocky benthic productivity and biodiversity have been reduced by sea urchins: in Norway (Norderhaug \& Christie 2009),
Mediterranean Sea (Falace \& Bressan 2002), eastern Canada (Lauzon-Guay \& Scheibling 2007), New Zealand (Shears \& Babcock 2002), Australia and New South Wales (Hill et al. 2003), Tasmania (Ling 2008) and the eastern Atlantic archipelagos (Hernández et al. 2008a).

Recruitment of Diadema aff. antillarum was spatialy and temporally variable and depended on preceding settlement rates, as has been found for other urchin species (Ebert 1983, Balch \& Scheibling 2000, Lamare \& Barker 2001). The smallest recruited D. aff. antillarum (4 to $6 \mathrm{~mm}$ TD) were recorded during November and December of every year, immediately after the settlement period (August-October). While recruitment intensity varied on a local scale, the lowest numbers of recruits were consistently observed in 2002, which is the year of lowest settlement rates that were possibly induced by the relatively cold water temperatures recorded in the preceding months. PS was positively correlated with temperature, as has been previously shown for other echinoids (Hart \& Scheibling 1988, Miller \& Emlet 1997), and varied markedly between studied islands. Factors such as settlement rate, predation, competition and migration may be important in determining PS rates (Tegner \& Dayton 1981, Keough \& Downes 1982, Balch \& Scheibling 2001). In urchin

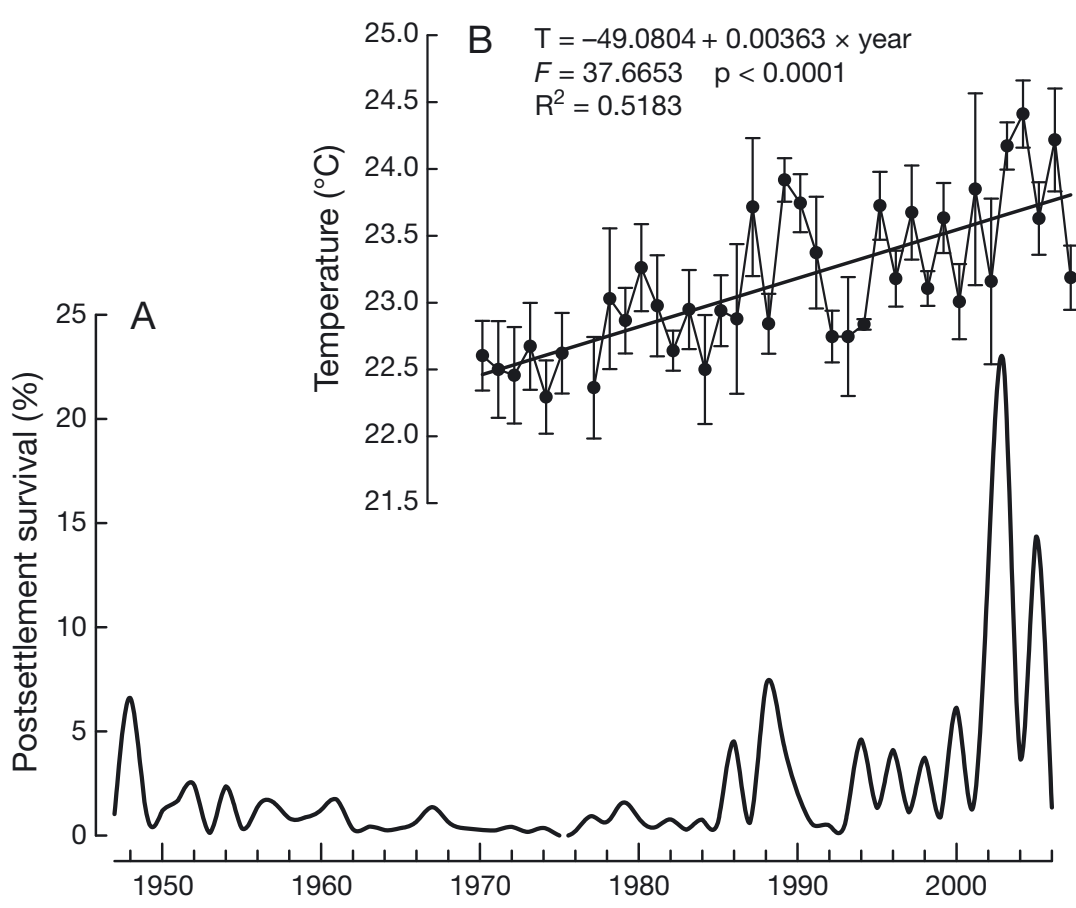

Fig. 6. Diadema aff. antillarum. (A) Reconstructed postsettlement survival pattern (PS) from 1948 to 2007 using historical sea surface temperature (SST) data. The previously obtained relationship between SST and PS (PS $=8.3565 \mathrm{E}-24$ $\exp (2.3045 \times \mathrm{T}))$ was used to reconstruct the historical PS pattern. (B) Long-term summer warming trend of coastal waters in the Canary Islands from 1970 to 2007. Sea temperatures are from Kalnay et al. (1996) reanalysis, averaged across settlement months (August-October) barren areas off Tenerife, where predation on sea urchin populations is very low (Clemente et al. 2007), PS was higher and was controlled by temperature oscillations. However, in macroalgal bed habitats of El Hierro Island, PS was very low to 0 . The increased mortality in these areas could be due to the high biomass of predatory fish and high predation rates (Clemente et al. 2009). Migration of juvenile sea urchins is very low or undetectable (Rowley 1989) and is not believed to be relevant in their spatial arrangement. Nonetheless, features inherent to stands of the brown algae Lobophora variegata, which are abundant in the macroalgal beds at El Hierro (Hernández et al. 2008b), may also affect PS. Alternatively, survival may be lower in these areas due to the complexity of macroalgal bed environments, or the absence of an appropriate habitat for early settlers (e.g. encrusting corallines, bacterial films and refuge, or the presence of earlier established adult urchins) (Cameron \& Schroeter 1980, Highsmith 1982, Levitan \& Genovese 1989, Pearce \& Scheibling 1990, Huggett et al. 2006). 


\section{Does temperature determine sea urchin abundance and barren formation?}

Since the early $80 \mathrm{~s}$, temperatures have been more favourable for Diadema aff. antillatum PS. However, it is at barren ground habitats where recruitment levels are highest. Well structured rocky bottom environments with high algal cover, as observed in El Hierro (Hernández et al. 2008b), seem to increase postsettlement mortality and limit urchin recruitment. However, healthy macroalgal bed environments are progressively becoming less common and are heavily constrained by intense grazing from existing sea urchins. Overfishing of predators is another wordwide phenomenon with effects that are known to cascade over the entire ecosystem (Worm et al. 2006), thereby aiding the growth of sea urchin populations. Alternatively, these alternate stable states are often cyclical; urchin densities can get very high at times but diseases can also erupt (Pearse et al. 1977, Scheibling 1986, Lessios 1988). Macroalgae at spatial refuges from urchins (shallow water, wave swept areas) then act as seed banks for times when urchin populations crash, thus allowing the system to rebound. Sea urchin mortality events are also expected to happen in the eastern Atlantic area since the seawater warming trend detected could increase the probability of pathogenic infections.

We have shown how 2 different sublittoral rocky bottom community states function in relation to environmental conditions at the eastern Atlantic islands. In urchin dominated barren habitats, seawater temperature is a major factor that influences the abundance of adult Diadema aff. antillarum via enhancement of PS, in the absence of strong predatory control (Clemente et al. 2009) since no mass mortality events were noticed. In healthy macroalgal bed habitats, habitat-specific factors constrain the influence of temperature over settlement processes and control sea urchin population establishment. Conservation policies need to focus on protecting healthy macroalgal bed habitats and the predatory fishes within them. A combination of healthy macroalgal coverage and abundant urchin predators is predicted to increase postsettlement mortality of $D$. aff. antillarum. Such management actions could improve ecosystem fuctioning by maintaining equilibrium between sea urchins and macroalgae, and could even mitigate the effects of seawater warming that will otherwise give sea urchins the upper hand.

Acknowledgements. J. M. Landeira and K. Toledo helped during settlement counting procedures. Dr. E. Cuevas provided long-term temperature data. J. Manning (Science Correct) greatly improved a previous draft of the manuscript. 'Ministerio de Educación y Ciencia del Gobierno de España' supported J.C.H. and S.C. with an FPU fellowship. We also thank the Ocean Science Division, Biological Oceanography of the US National Science Foundation for its current support to J.C.H. through a postdoctoral fellowship.

\section{LITERATURE CITED}

Anderson MJ (2001) Permutational tests for univariate or multivariate analysis of variance and regression. Can J Fish Aquat Sci 58:626-639

Bak RPM (1985) Recruitment patterns and mass mortalities in the sea urchin Diadema antillarum. Proc 5th Int Coral Reef Congr 5:267-272

> Balch T, Scheibling RE (2000) Temporal and spatial variability in settlement and recruitment of echinoderms in kelp beds and barrens in Nova Scotia. Mar Ecol Prog Ser 205: 139-154

Balch T, Scheibling RE (2001) Larval supply, settlement and recruitment in echinoderms. In: Jangoux M, Lawrence JM (eds) Echinoderm studies, 6. AA Balkema, Rotterdam, p 1-83

Boidron-Metairon IF (1995) Larval nutrition. In: McEdward L (ed) Ecology of marine invertebrate larvae. CRC Press, Marine Science Series, FL, p 223-248

Braun JG, Molina R (1984) El Mar. El Atlántico en el área de Canarias. In: Concepción R (ed) Geografía de Canarias. Interinsular Canaria, La Laguna, p 18-28

> Caley MJ, Carr MH, Hixon MA, Hughes TP, Jones GP, Menge BA (1996) Recruitment and the local dynamics of open marine populations. Annu Rev Ecol Syst 27: 477-500

Cameron RA, Schroeter SC (1980) Sea urchin recruitment: effect of substrate selection on juvenile distribution. Mar Ecol Prog Ser 2:243-247

Clemente S (2007) Evolución de las poblaciones del erizo Diadema aff. antillarum en Canarias y valoración de la depredación como factor de control. PhD dissertation, Universidad de La Laguna, Tenerife

Clemente S, Hernández JC, Toledo K, Brito A (2007) Predation upon Diadema aff. antillarum in barren grounds in the Canary Islands. Sci Mar 71:745-754

Clemente S, Hernández JC, Brito A (2009) Evidence of the top-down role of predators in structuring sublittoral rockyreef communities in a marine protected area and nearby areas of the Canary Islands. ICES J Mar Sci 66:64-71

> Connell JH (1985) The consequences of variation in initial settlement vs. post-settlement mortality in rocky intertidal communities. J Exp Mar Biol Ecol 93:11-45

Ebert TA (1983) Recruitment in echinoderms. In: Lawrence JM, Jangoux M (eds) Echinoderm studies. AA Balkema, Rotterdam, p 169-203

Ebert TA, Schroeter SC, Dixon JD, Kalvass P (1994) Settlement patterns of red and purple sea urchins (Strongylocentrotus franciscanus and $S$. purpuratus) in California, USA. Mar Ecol Prog Ser 111:41-52

Eckert GL (1998) Larval development, growth and morphology of the sea urchin Diadema antillarum. Bull Mar Sci 63:443-451

Falace A, Bressan G (2002) A qualitative and quantitative analysis of the evolution of macroalgal vegetation on an artificial reef with anti-grazing nets (Loano-Ligurian Sea). ICES J Mar Sci 59:S150-S156

- Guidetti P, Sala E (2007) Community-wide effects of marine reserves in the Mediterranean Sea. Mar Ecol Prog Ser 335: $43-56$

> Hagen NT (1995) Recurrent destructive grazing of successionally immature kelp forest by green sea urchins in Vestfjorden, Northern Norway. Mar Ecol Prog Ser 123: 95-106

Harley CDG, Hughes AR, Hultgren KM, Miner BG and others (2006) The impacts of climate change in coastal marine systems. Ecol Lett 9:228-241 
Harrold C, Lisin S, Light KH, Tudor S (1991) Isolating settlement from recruitment of sea urchins. J Exp Mar Biol Ecol 147:81-94

Hart MW, Scheibling RE (1988) Heat waves, baby booms, and the destruction of kelp beds by sea urchins. Mar Biol 99:167-176

> Hawkins CM, Lewis JB (1982) Ecological energetics of the tropical sea urchin Diadema antillarum Philippi in Barbados, West Indies. Estuar Coast Shelf Sci 15: 645-669

Hereu B, Zabala M, Linares C, Sala E (2004) Temporal and spatial variability in settlement of the sea urchin Paracentrotus lividus in the NW Mediterranean. Mar Biol 144: 1011-1018

Hernández JC (2006) Estrategia reproductiva de la población canaria del erizo Diadema aff. antillarum Philippi, 1845: maduración gonadal, asentamiento larvario y reclutamiento. PhD dissertation, Universidad de La Laguna, Tenerife

Hernández JC, Brito A, Cubero E, Girard D, GonzálezLorenzo G, Falcón JM (2006a) Temporal patterns of larval settlement of Diadema antillarum (Echinodermata: Echinoidea) in the Canary Islands using an experimental larval collector. Bull Mar Sci 78:271-279

> Hernández JC, Brito A, García N, Gil-Rodríguez MC, Herrera G, Cruz-Reyes A, Falcón JM (2006b) Spatial and seasonal variation of the gonad index of Diadema antillarum (Echinodermata: Echinoidea) in the Canary Islands. Sci Mar 70:689-698

> Hernández JC, Clemente S, Sangil C, Brito A (2008a) The key role of the sea urchin Diadema aff. antillarum in controlling macroalgae assemblages throughout the Canary Islands (eastern subtropical Atlantic): a spatio-temporal approach. Mar Environ Res 66:259-270

> Hernández JC, Clemente S, Sangil C, Brito A (2008b) Actual status of the sea urchin Diadema aff. antillarum populations and macroalgal cover in marine protected areas compared to a highly fished area (Canary Islands - eastern Atlantic Ocean). Aquat Conserv 18:1091-1108

Highsmith RC (1982) Induced settlement and metamorphosis of sand dollar (Dendraster excentricus) larvae in predatorfree sites: adult sand dollar beds. Ecology 63:329-337

Hill NA, Blount C, Poore AGB, Worthington D, Steinberg PD (2003) Grazing effects of the sea urchin Centrostephanus rodgersii in two contrasting rocky reef habitats: effects of urchin density and its implications for the fishery. Mar Freshw Res 54:691-700

> Himmelman JH (1986) Population biology of green sea urchins on rocky barrens. Mar Ecol Prog Ser 33:295-306

Hoegh-Guldberg O, Pearse JS (1995) Temperature, food availability, and development of marine invertebrate larvae. Am Zool 35:415-425

> Huggett MJ, Williamson JE, de Nys R, Kjelleberg S, Steinberg PD (2006) Larval settlement of the common Australian sea urchin Heliocidaris erythrogramma in response to bacteria from the surface of coralline algae. Oecologia 149: $604-619$

Hughes TP, Bellwood DR, Folke C, Steneck RS, Wilson J (2005) New paradigms for supporting the resilience of marine ecosystems. Trends Ecol Evol 20:380-386

IPCC (2007) Climate change 2007: the physical science basis. Contribution of Working Group I to the Fourth Assessment Report of the Intergovernmental Panel on Climate Change. Cambridge University Press, Cambridge

Kalnay E, Kanamitsu M, Kistler R, Collins W and others (1996) The NCEP/NCAR 40-year reanalysis project. Bull Am Meteorol Soc 77:437-471
Keesing JK, Cartwright CM, Hall KC (1993) Measuring settlement intensity of echinoderms on coral reefs. Mar Biol 117:399-407

Keough MJ, Downes BJ (1982) Recruitment of marine invertebrates: the role of active larval choices and early mortality. Oecologia 54:348-352

Knowlton N (2004) Multiple 'stable' states and the conservation of marine ecosystems. Prog Oceanogr 60:387-396

> Lamare MD, Barker MF (2001) Settlement and recruitment of the New Zealand sea urchin Evechinus chloroticus. Mar Ecol Prog Ser 218:153-166

Lauzon-Guay JS, Scheibling RE (2007) Seasonal variation in movement, aggregation and destructive grazing of the sea urchin (Strongylocentrotus droebachiensis) in relation to wave action and sea temperature. Mar Biol 151: 2109-2118

Lawrence JM (1975) On the relationships between marine plants and sea urchins. Oceanogr Mar Biol Annu Rev 13: 213-286

Lessios HA (1988) Mass mortality of Diadema antillarum in the Caribbean: What have we learned? Annu Rev Ecol Syst 19:371-393

> Levitan DR, Genovese SJ (1989) Substratum-dependent predator-prey dynamics: patch reefs as refuges from gastropod predation. J Exp Mar Biol Ecol 130:111-118

Ling SD (2008) Range expansion of a habitat-modifying species leads to loss of taxonomic diversity: a new and impoverished reef state. Oecologia 156:883-894

> Ling SD, Johnson CR, Frusher S, King CK (2008) Reproductive potential of a marine ecosystem engineer at the edge of a newly expanded range. Glob Change Biol 14: 907-915

McAlister JS (2008) Evolutionary response to environmental heterogeneity in central American echinoderm larvae: plastic versus constant phenotypes. Evolution 62:1358-1372

McEdward LR, Miner BG (2001) Echinoid larval ecology. In: Lawrence JM (ed) Edible sea urchins: biology and ecology. Elsevier, Amsterdam, p 59-78

> Miller BA, Emlet RB (1997) Influence of nearshore hydrodynamics on larval abundance and settlement of sea urchins Strongylocentrotus franciscanus and $S$. purpuratus in the Oregon upwelling zone. Mar Ecol Prog Ser 148:83-94

Norderhaug KM, Christie HC (2009) Sea urchin grazing and kelp re-vegetation in the NE Atlantic. Mar Biol Res 5: 515-528

> Pearce CM, Scheibling RE (1990) Induction of metamorphosis of larvae of the green sea urchin, Strongylocentrotus droebachiensis, by coralline red algae. Biol Bull 179:304-311

Pearse JS, Costa DP, Yellin MB, Agegian CR (1977) Localized mass mortality of red sea urchins, Strongylocentrotus franciscanus, near Santa Cruz, California. Fish Bull 75: 645-648

Pinnegar JK, Polunin NVC, Francour P, Badalamenti F and others (2000) Trophic cascades in benthic marine ecosystems: lessons for fisheries and protected-area management. Environ Conserv 27:179-200

Roughgarden J, Gaines S, Possingham H (1988) Recruitment dynamics in complex life cycles. Science 241:1460-1466

Rowley RJ (1989) Settlement and recruitment of sea urchins (Strongylocentrotus spp.) in a sea-urchin barren ground and a kelp bed: Are populations regulated by settlement or post-settlement processes? Mar Biol 100:485-494

> Scheibling RE (1986) Increased macroalgal abundance following mass mortalities of sea urchins (Strongylocentrotus droebachiensis) along the Atlantic coast of Nova Scotia. Oecologia 68:186-198 
Scheibling RE (1996) The role of predation in regulating sea urchin populations in eastern Canada. Oceanol Acta 19: 421-430

Shears NT, Babcock RC (2002) Marine reserves demonstrate top-down control of community structure on temperate reefs. Oecologia 132:131-142

Sivertsen K (2006) Overgrazing of kelp beds along the coast of Norway. J Appl Phycol 18:599-610

Starr M, Himmelman JH, Therriault JC (1990) Direct coupling of marine invertebrate spawning with phytoplankton blooms. Science 247:1071-1074

Steeman-Nielsen E (1952) Use of radioactive carbon (C14) for measuring organic production in the sea. J Cons Int Explor Mer 18:117-140

Steneck RS, Graham MH, Bourque BJ, Corbett D, Erlandson JM, Estes JA, Tegner MJ (2002) Kelp forest ecosystems: biodiversity, stability, resilience and future. Environ Conserv 29:436-459

Editorial responsibility: James McClintock, Birmingham, Alabama, USA
Tegner MJ, Dayton PK (1981) Population structure, recruitment and mortality of two sea urchins (Strongylocentrotus franciscanus and $S$. purpuratus) in a kelp forest. Mar Ecol Prog Ser 5:255-268

Thorson G (1950) Reproduction and larval ecology of marine bottom invertebrates. Biol Rev Camb Philos Soc 25: $1-45$

Uthicke S, Schaffelke B, Byrne M (2009) A boom-bust phylum? Ecological and evolutionary consequences of density variations in echinoderms. Ecol Monogr 79: $3-24$

Watanabe J, Harrold C (1991) Destructive grazing by sea urchins Strongylocentrotus spp. in a central California kelp forest: potential roles of recruitment, depth, and predation. Mar Ecol Prog Ser 71:125-141

- Worm B, Barbier EB, Beaumont N, Duffy JE and others (2006) Impacts of biodiversity loss on ocean ecosystem services. Science 314:787-790

Submitted: November 6, 2009; Accepted: May 31, 2010

Proofs received from author(s): August 14, 2010 